\title{
Development of the logistics and transport system of organic products as a perspective direction of Ukraine's environmental strategy
}

\author{
Kateryna Bogomolova ${ }^{1}$, Viktoriia $\mathrm{Kralia}^{1}$, Olha Podolska $^{1}$, Yuliia Sahachko $^{1}$, and Olena \\ Smihunova ${ }^{1}$ \\ ${ }^{1}$ Petro Vasylenko National Technical University of Agriculture, Department of Organization of \\ Production, Business and Management, 44 Artema Str., 61002 Kharkiv, Ukraine
}

\begin{abstract}
The state of development of the organic market in Ukraine is analyzed. Shown that organic agriculture is currently positioned in the country as one of the key direction to increase the level of environmental friendliness, economic feasibility in agriculture and is a progressive way to improve the balance between environmental and economic factors of society. The dynamics of changes in the number of organic farms and the area of their agricultural lands is considered. The analysis of the development of the Ukrainian domestic market of consumption of organic products is carried out, and also the dynamics of import of certified organic products from Ukraine to the EU is investigated. Relevance of the issue of logistics by road and rail is proved. The state and main problems of the transport infrastructure of Ukraine are considered. Emphasized that to improve the logistics needs strong institutions, effective coordination of state and government support at the highest level. The development of strategic directions for the improvement of the logistics and transport system is proposed in order to strengthen the competitive position of Ukrainian agricultural producers in the world market of organic products and intensify the integration of the state into the international economic space.
\end{abstract}

\section{Introduction}

Today's realities make it clear that the well-being of present and future generations and the level of national environmental security depend on the results of economic entities in all spheres of the national economy. Chosen type of products or services through applied technology they directly affect the environment, as environmental or low-waste technologies will cause much less damage to the environment than intensive and environmentally unsafe.

Thus, the environmental component affects all aspects of the enterprise, namely cooperation with business partners, state environmental control bodies, financial and credit organizations, mutual understanding with the public and as a result on the internal strategy of the organization and management decision-making mechanisms [1]. Clearly, by taking

* Corresponding author: o podolskaya@ukr.net 
into account the opportunities and risks related with environmental problems depends on a successful business.

The practice of modern environmental concept at enterprises in both domestic and foreign markets is not possible without the use of a new format of business. Namely, to integrate all economic subjects involved: producers (goods and services), suppliers of raw materials and components, trade and logistics companies, consumers and other stakeholders into a single environmental cycle. And also to work closely with organizations that promote products on the market, and ensure success in competition, and form the image of an environmentally friendly enterprise. Therefore, the use of environmental management in enterprises is a relatively new phenomenon in the world economy, which can be defined as a special management system aimed at preserving the quality of the environment, ensuring regulatory environmental parameters and based on the concept of sustainable development of society.

Not the best state of the environment, worsening statistics of oncological diseases, force the population to reconsider their attitude to food are daily present at their table. After, understanding the relationship between the state of the environment and product quality, and as a result, human health, leads to a rethinking of food culture and awareness of the value of an ecological product.

\section{Features and logistical problems of organic producers in Ukraine}

The constantly growing interest in organic food around the world allows Ukrainian farmers to be as full participants in this market, because the available resource potential, technology, provide an opportunity to ensure sustainable competitive advantages. All of the above contributes to the development of ecological or organic agricultural production in our country [2].

Organic agricultural production is an integrated system that combines the best practices in view of environmental protection, maintenance of biological diversity, conservation of natural resources, high standards and production methods. The development of organic agricultural production is a topical and at the same time controversial issue of the functioning of agricultural formations in a competitive environment.

Discussions among scientists and practitioners about the economic feasibility and organizational possibilities of introducing organic production in agricultural formations are related to the conditions of imbalance of the external environment, functioning, increased competition and intensification of the effects of the global environment. The immediate impact exercise existing level and structure of the quality requirements for consumer products, the prospects of integration into the European market, requiring strengthening efforts towards the production of environmentally safe products. At the same time, many years of foreign experience demonstrates the economic, environmental and social benefits of organic production (Fig. 1) [6].

The ecological benefits of organic production are undeniable, it's high-quality food, minimal damage to the environment, ensuring ecological balance at each stage of production, sales of organic products. Spreading of organic production in different countries of the world gives Ukraine the opportunity to find its place among producers and get an additional opportunity to attract investment, financial resources and prospects for innovation. 


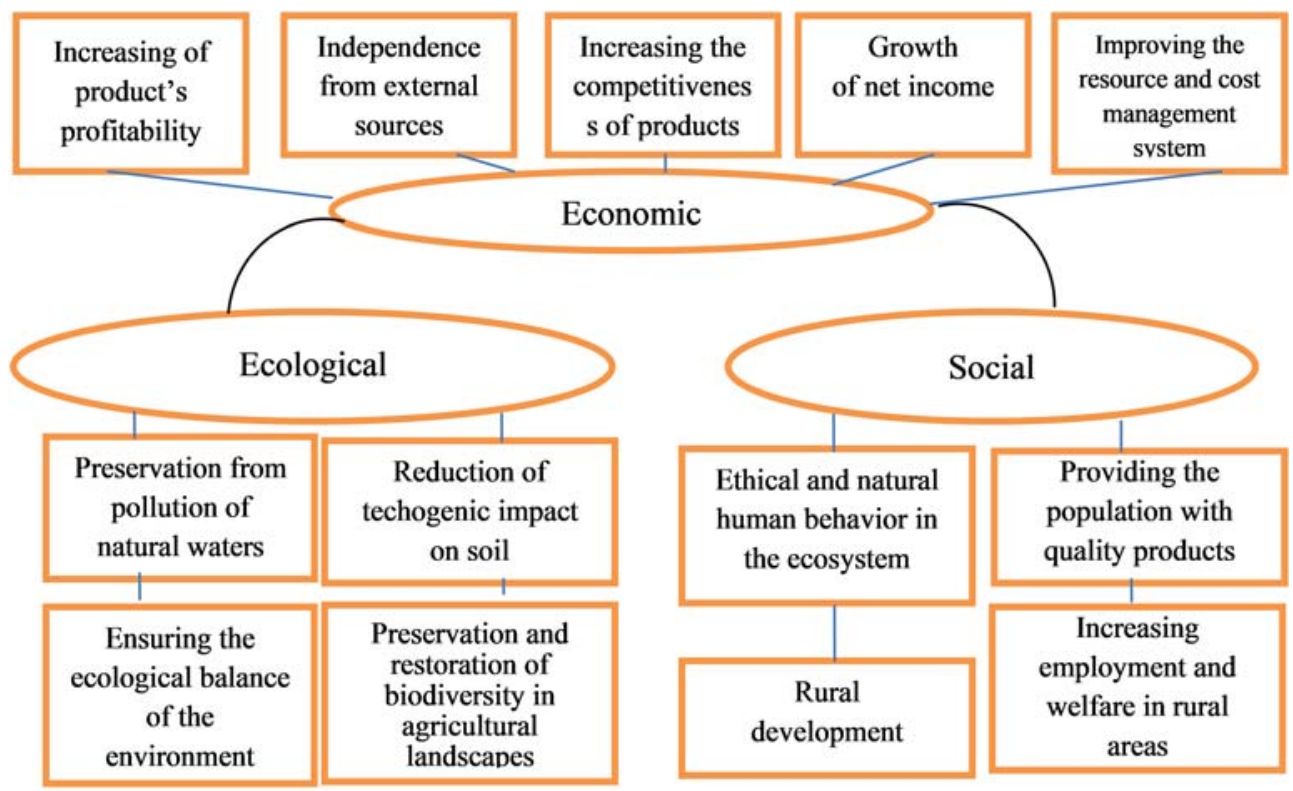

Fig.1. Key benefits of organic production in the world.

Organic products currently in high demand worldwide, and the number of producers is increasing annually. Organic agriculture is tolerant of the environment and is based on the principles of ecology - the science of the environment, and the deep laws of biology - a combination of sciences of natural world. Therefore, it can be argued that organic agriculture is essentially both ecological and biological. Therefore, the use of the terms "ecological" and "biological" does not contradict EU regulatory directives when it comes to organic agriculture. [6,9].

In 2019 Ukraine took the second place among countries exporting organic products to the EU, behind only China. The part of Ukrainian organic products in the markets of European countries was $10.4 \%$. he European countries that import the most organic products are the Netherlands, Germany, Austria, Poland, Lithuania and others. (Fig.2). These are mainly cereals and oilseeds, oilcake, fruits, vegetables and fruit juices.

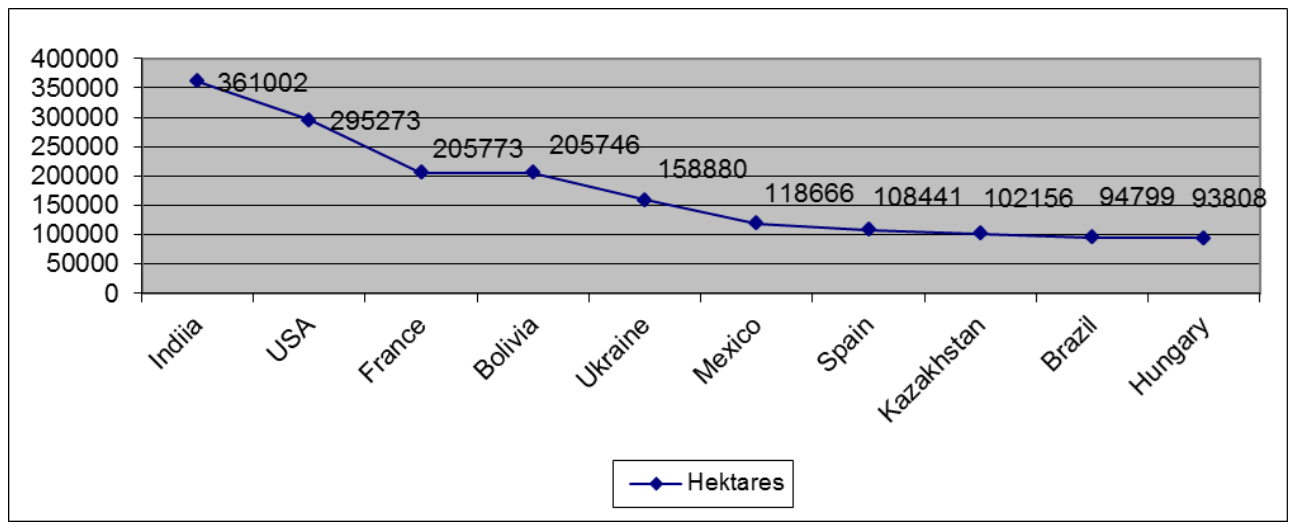

Fig.2. The structure of imports of Ukrainian organic products in the EU. 
However, only about $1 \%$ of cultivated land in Ukraine is currently occupied by organic farming. Although Ukraine is among the 10 countries with the largest increase in organic agricultural land (Fig. 3).

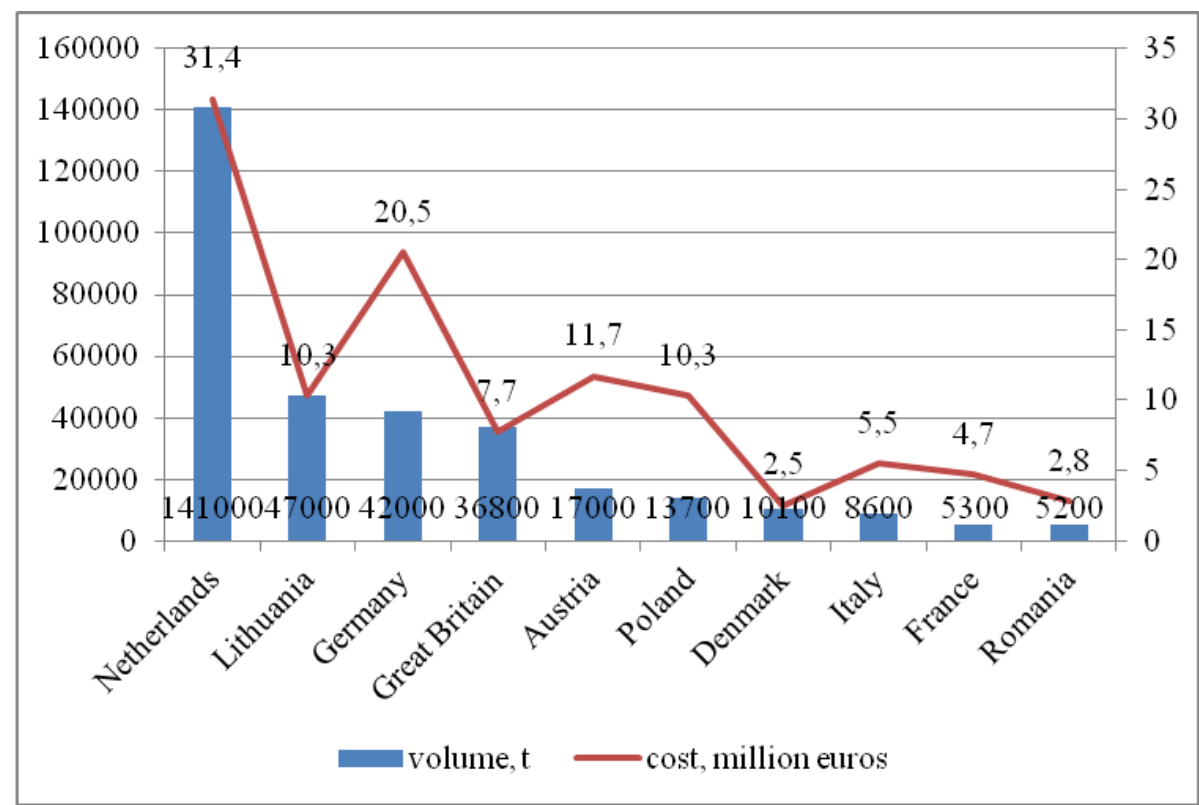

Fig. 3. World: the ten countries with the highest increase of organic agricultural land 2019).

* Source: FiBL survey 2021, based on data from government bodies, the private sector, and certifiers. For detailed data sources see annex (International, Bonn. Available at https://www.organicworld.net/yearbook/yearbook-2019.html).

Factors that constraining Ukrainian farmers fo implementing organic farming technologies are the difficulty of complying with the relevant technological requirements; lower production productivity compared to intensive production technologies, and, as a consequence, the inability to obtain sufficient raw materials capable of ensuring food security of the country, lack of domestic demand for organic products due to low solvency of consumers and so on.

At the same time, analytical data from the commercial service of the US Embassy in Ukraine show that the average return on investment in Ukrainian organic farming is about $300 \%$, which makes it one of the most attractive direction for investment in Ukraine [3]. Often companies in the country have projects on introduction of organic farming with the support of foreign companies (primarily Swiss, Dutch, German) [4].

Promotion of organic agricultural production is also facilitated by public organizations and associations, whose activities are aimed at intensifying the joint efforts of all stakeholders (producers, research and educational institutions, other enterprises, individuals and organizations) in the production and distribution of healthy, environmentally friendly products [9].

Currently, Ukrainian farmers specializing mainly in organic crop production. The total area of agricultural land certified by "Organic Standard" in 2019 amounted to 309,100 thousand hectares, including 233,500 - lands with organic status. At the same time, there were 635 operators of the organic market, of which 501 were agricultural producers [5]. During the cultivation of cereals was $48.1 \%$ of land certified as organic, which puts Ukraine in seventh place among producers of organic grain [3]. 
Organic production involves fertile soils, which without the use of mineral fertilizers are able to provide stable crop yields. The main requirements are strict adherence to crop rotations, application of organic fertilizers and inclusion in the structure of green manure crops to provide nutrients and reproduction of humus in the soil [6].

Today, Ukrainian producers of agricultural products in conditions of fierce competition in the markets have only way to survive is the production and export of organic agricultural products. To export activity by entering into direct contracts today are able to only holdings with strong land bank, excellent reputation and financial independenceAt the same time, small organic producers are practically deprived of such an opportunity due to the influence of the following factors: interest of foreign importing companies in large batches of products, significant transport and overhead costs, which makes the sale of small batches economically unprofitable; absence of developed logistics infrastructure and high logistics risks [11].

Most of farmland are under organic production in southern Ukraine, namely in Odessa and Kherson regions. Today in the Odessa region about 100,000 hectares are certified according to international organic standards. This concentration is due to the natural location of the waterways and the seaport. Therefore, the logistics infrastructure is developed in these areas and therefore plant products are supplied here for storage and further shipment to foreign customers by ship transport.

Some organic agricultural producers from other regions of the land bank of 3,000 hectares or more, which previously shipped products to car trucks are considering the possibility of access to seaports. The only barrier for them is transportation within the country that can increase product price to 20 euros / ton. Therefore, the issue of logistics of road and rail transport is still very topical. Another topical issue is the modernization of terminals in sea and river ports for organic specifics.

\section{Strategic directions of solving specified problems}

Agri-food sector Ukraine has significant potential for the promotion of organic products both on the domestic and external consumer and industrial markets. One of the ways to achieve this potential is to develop the segment of transport logistics for the promotion of organic products, which is in demand among consumers in the world, and its supply is insufficient in terms of quality content.

The vast majority of Ukrainian organic agricultural products are exported from Ukraine through seaports. Ship deliveries are one of the most economically attractive types of delivery for some countries, and among the advantages is the economic feasibility of forming large batches. In Ukraine there are 33 grain terminals with a maximum capacity 50 million tons Grain per year.

Among the disadvantages of transportation by sea are:

- very long term delivery;

- high risk of pollution or contamination;

- risk of loss or damage due to leaks in holds.

Currently, the transportation of organic products in Ukraine is carried out in the following ways - by rail, water and road (Table 1).

Currently, the factor hindering grain exports is logistical and transport difficulties with grain transshipment. For example, in Ukraine there are currently more than a thousand elevators, which allow power to ship daily to 700 thousand tons of grain. At the same time, Ukrainian Railways wagons are enough to export only 100,000 tons of grain. According to the World Bank, unsatisfactory logistics in the agro-industrial sector is the reason for producers not receiving 0.6-1.6 billion dollars [12]. 
As for granaries, the vast majority of elevators in Ukraine have a low level of mechanization and need modernization. As of the beginning of 2019, the domestic capacity for simultaneous storage of grain and oilseeds amounted to about 72 million tons with a volume to be stored of 90 million tons, ie the deficit of storage capacity was almost 18 million tons [8].

Table 1. State and problems of transport infrastructure of Ukraine.

\begin{tabular}{|c|c|c|c|}
\hline $\begin{array}{c}\text { Type of transport } \\
\text { infrastructure }\end{array}$ & Advantage & Problems & Ways to solve \\
\hline $\begin{array}{l}\text { Rail transport (about } \\
60 \% \text { of total grain } \\
\text { traffic) }\end{array}$ & $\begin{array}{l}\text { - transportation of grain } \\
\text { in containers } \\
\text { guarantees quality; } \\
\text { - provides convenience } \\
\text { during transportation of } \\
\text { grain in special } \\
\text { containers, } \\
\text { - the problem of } \\
\text { unloading of highways } \\
\text { is solved }\end{array}$ & $\begin{array}{l}\text { - delay in the allocation of } \\
\text { grain wagons during } \\
\text { periods of active grain } \\
\text { exports; } \\
\text { - deterioration of } \\
\text { Ukrainian Railways } \\
\text { production indicators } \\
\text { (reduction of average } \\
\text { speed, deterioration of } \\
\text { grain truck turnover, } \\
\text { reduction of cargo } \\
\text { transportation due to grain } \\
\text { truck surplus). }\end{array}$ & $\begin{array}{l}\text { - clear rules and rates the } \\
\text { use of railway } \\
\text { infrastructure; } \\
\text { - gradual accumulation of } \\
\text { private companies' own } \\
\text { fleet of hoppers. }\end{array}$ \\
\hline $\begin{array}{l}\text { River transport } \\
\text { (about } 3 \% \text { of total } \\
\text { grain transportation) }\end{array}$ & $\begin{array}{l}\text { - a more economically } \\
\text { attractive type of grain } \\
\text { movement due to } \\
\text { minimal costs }\end{array}$ & $\begin{array}{l}\text { - shortage of coasting } \\
\text { fleet in Ukraine; } \\
\text { - uncontrolled discharge } \\
\text { of hydropower water; } \\
\text { - the existence of barriers } \\
\text { to access to foreign ships } \\
\text { in the internal waters of } \\
\text { Ukraine. }\end{array}$ & $\begin{array}{l}\text { - extensive work on } \\
\text { dredging rivers; } \\
\text { - extension of the } \\
\text { navigation period in the } \\
\text { winter period of the year } \\
\text { (November - March); } \\
\text { - reforming the } \\
\text { navigation system to } \\
\text { modern standards, } \\
\text { - optimization of } \\
\text { gateways and } \\
\text { drawbridges; } \\
\text { - simplification of } \\
\text { permitting procedures } \\
\text { and reduction of tariffs } \\
\text { for navigation services }\end{array}$ \\
\hline $\begin{array}{l}\text { Road transport } \\
\text { (about 36\% of all grain } \\
\text { traffic volumes) }\end{array}$ & $\begin{array}{l}\text { - timeliness of product } \\
\text { deliveries during } \\
\text { periods of active } \\
\text { railway loading; } \\
\text { - relatively low cost of } \\
\text { transportation by road } \\
\text { due to fierce } \\
\text { competition in the } \\
\text { market of } \\
\text { transportation services. }\end{array}$ & $\begin{array}{l}\text { - destruction of the road } \\
\text { surface and increase of } \\
\text { carbon emissions into the } \\
\text { atmosphere; } \\
\text { - shortage of drivers; } \\
\text { - downtime for loading } \\
\text { and unloading due to the } \\
\text { weak organization of } \\
\text { automobile logistics; } \\
\text { - violation by agricultural } \\
\text { producers of the rules of } \\
\text { transportation of organic } \\
\text { products; } \\
\text { - transshipment of } \\
\text { transport by grain; } \\
\text { - shadow markets of car } \\
\text { services and fuel. }\end{array}$ & $\begin{array}{l}\text { - introduction of services } \\
\text { for automation of } \\
\text { automobile logistics (for } \\
\text { example, Jit + and } \\
\text { Zernovoz); } \\
\text { - creation of automated } \\
\text { points of dimensional and } \\
\text { weight control; } \\
\text { - reorientation of the } \\
\text { market to the production } \\
\text { and purchase of } \\
\text { equipment for the } \\
\text { transportation of grain } \\
\text { with a lightweight design. }\end{array}$ \\
\hline
\end{tabular}


In order to encourage farmers to build their own granaries Ukraine government developed a program of compensation for $30 \%$ of their construction, in that in 2019 allocated 850 million UAH. However, even under such conditions, only agroholding can afford to build their own storage facilities.

To solve the problems of development and improve transport and logistics infrastructure necessary government regulation to encourage competition and create a favorable investment environment and facilitate the creation of additional jobs and value added products [7].

Efficient trade and transport logistics are key to developing the competitiveness of countries around the world. Therefore, it is important to develop strategic directions for the development of the logistics and transport system in Ukraine (Fig. 4.).

Improving logistics services requires strong institutions, effective public sector coordination and the highest level of government support. Transportation of goods often requires the efficient operation of many links in the supply chain. Efficient logistics is also important for the internal market to available, safe and reliable transport and other logistics services could help Ukrainian economy to develop stably own economic, social and environmental aspects [10].

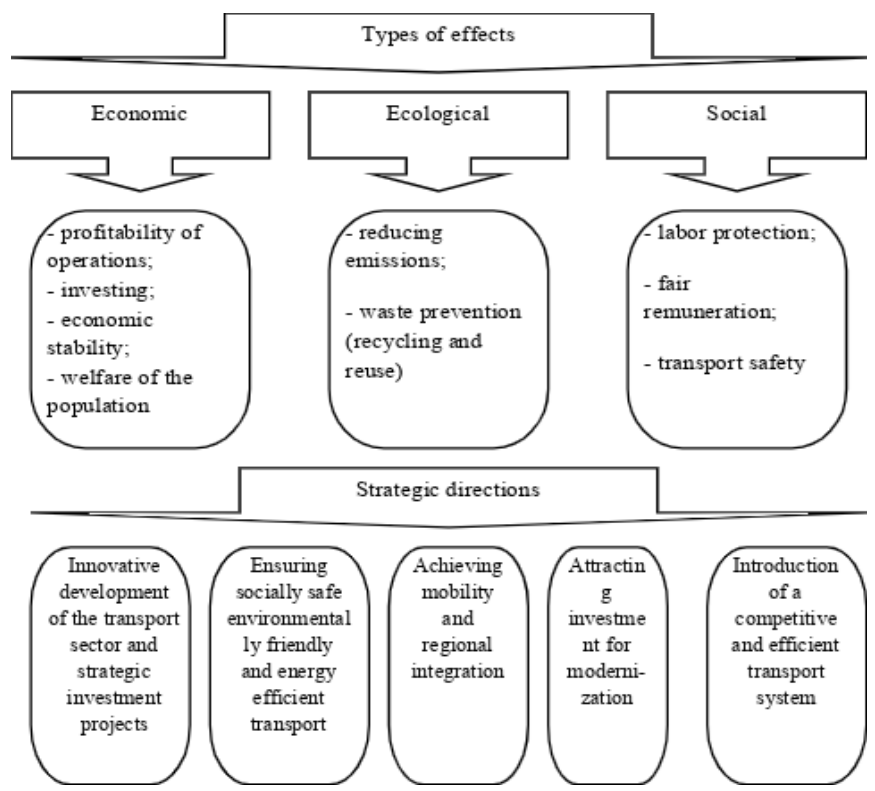

Fig. 4. Strategic directions of development of logistics and transport system in Ukraine.

\section{Conclusions}

So, with the popularization of healthy lifestyle in the world and in Ukraine relevance of organic products is growing. Ukrainian society is increasingly interested in what is "organic products" or "organic production", which is a consequence of increasing the volume of organic products.

Ukraine, having an agricultural potential, has all the opportunities to fully join the global organic movement with the prospect of becoming a leading supplier of high quality certified products not only to the European market but also to the growing Asian and American markets. In addition, the socio-economic and environmental benefits of organic for Ukrainian society deserve special attention. 
Established that, despite significant potential for the production of organic agricultural products, domestic enterprises face a number of obstacles, and especially with imperfect transport logistics. Strategic directions and main ways to address this issue for Ukraine have been developed. This requires a pruden investment policy of stakeholders and government support.

\section{References}

1. Shabinskyy, O., Eevdokimova, M., \& Furdak, M. (2017). Economic nature and scientific and methodological principles of management of economic security of the agricultural sector. Visnyk of the Kharkiv National Technical University of Agriculture named after P.Vasilenko, 182, 47-59.

2. Bagorka, M.O. (2017). State and problems of development of the market of organic products in Ukraine. Black Sea Economic Studies, (14), 29-33.

3. Agropolit (2018). Analysis of the market of organic products in Ukraine.. https://agropolit.com/spetsproekty/407-analiz-rinku-organichnoyi-produktsiyi-vRetrived from ukrayini/

4. Wdowith, V.G., \& Cherkaska, I.S. (2013). The state of organic production in Ukraine. NUBIP Ukr. Ser. Economics, agricultural management, business, 181(6), 408.

5. Ministry for Development of Economy, Trade and Agriculture of Ukraine (2021). Organic production in Ukraine.. https://agro.me.gov.ua/ua/napryamki/organichnevirobnictvo/organichne-virobnictvo-v-ukrayini

6. Smihunova, O.V., \& Ilyin, O.A. (2020) State and prospects of development of organic production in Ukraine. Ukrainian Journal of Applied Economics, 5(4), 98-105.

7. Krylov, Ya.O. (2018). Main directions of grain market development and mechanism of its regulation in Ukraine. Ukrainian Journal of Applied Economics, 3(3), 43-53.

8. Ilchuk, M.M., Konoval, I.A., \& Baranovska, O.D. (2019). Development of the grain market in Ukraine and its stabilization. Economika APK, (4), 29-38. http://eapk.org.ua/en/contents/2019/04/29

9. Minenko, S.I., \& Dudnik, O.V. (2020). Organic agriculture as a source of increasing the competitiveness of Ukraine in the international arena. Materials of the VII International scientific and practical conference "Actual problems of innovative development and staffing of the agro-industrial complex", June 4-5, 2020, Belarus.

10. Ambarexport (2019). Logistics for grain export. https://ambarexport.ua/blog/grainexport-logistics

11. Goncharenko, N. (2018). Clustering as a tool to increase the competitiveness of organic crop production in conditions of international competition. State and Regions, (4), $106-112$.

12. Lb.Ua (2016) Grain logistics in Ukraine: barriers to export growth. https://lb.ua/economics/2016/08/15/342521 logistika_zernovih_ukraini.html 